\title{
Do Impressionismo à arte abstrata: a influência da fotografia e das teorias da percepção
}

\author{
CAVALCANTE, Neusa ${ }^{1}$ \\ 1Universidade de Brasília, Brasília, Brasil. neusa.cavalcante2@gmail.com
}

\section{Resumo}

Este artigo propõe uma reflexão sobre como o surgimento do Impressionismo, importante transformação da expressão pictórica rumo à arte abstrata, foi influenciado pelo desenvolvimento da fotografia e pelas teorias sobre a percepção humana da cor e da forma (Gestalt). Este esforço é parte de uma pesquisa mais ampla sobre fatos e feitos históricos determinantes da construção do ideário moderno e também da formulação da arte abstrata, em geral, e do Impressionismo, em particular ${ }^{1}$.

Palavras-chave: Impressionismo; fotografia; percepção da cor; percepção da forma.

\begin{abstract}
This article proposes a reflection on how the emergence of Impressionism, important transformation of pictorial expression towards abstract art, was influenced by photography development and by theories about human perception of color and form (Gestalt). This effort is part of a broader survey of historical facts and events that were decisive for the construction of modern ideary and also for the formulation of abstract art in general and of Impressionism in particular ${ }^{1}$.
\end{abstract}

Keywords: Impressionism; photography; color perception; perception of form.

\footnotetext{
1 O objetivo da pesquisa é estabelecer a contribuição, para o surgimento da arte abstrata, de eventos tais como: a Revolução Industrial; advento e popularização da fotografia; invenção do avião; a Primeira Guerra; a Revolução Bolchevique; O capital, de Karl Marx; A interpretação dos sonhos, de Sigmund Freud, e as teorias sobre a percepção humana de cores e formas.

1 The research aim consists in establishing the contribution of several events, such as: Industrial Revolution; advent and popularization of photography; airplane invention; First War; Bolshevik Revolution; Karl Marx's Capital; Sigmund Freud's Interpretation of dreams and the theories on human perception of colors and forms, for the emergence of abstract art.
} 


\section{A fotografia e a arte pictórica}

A popularização da fotografia, que estreitou a relação entre artistas plásticos e fotógrafos nos finais do século XIX na Europa, e também as novas descobertas sobre a percepção humana de formas e cores estiveram nas origens da arte moderna, ou mais especificamente da arte abstrata.

Pode-se dizer que a pesquisa artística moderna começou com o Impressionismo, movimento que, formado em Paris entre 1860 e 1870, foi apresentado ao público, pela primeira vez, em 1874. A realização da exposição coletiva das obras de Oscar-Claude Monet, Pierre-Auguste Renoir, Edgar Hilaire Dégas, Paul Cézanne, Jacob Camille Pissarro e Alfred Sisley no estúdio do fotógrafo Félix Nadar ${ }^{2}$ (figura 1) não parece desprovida de sentido.

Figura 1: Estúdio de Félix Nadar, no № 35, Boulevard des Capucines.

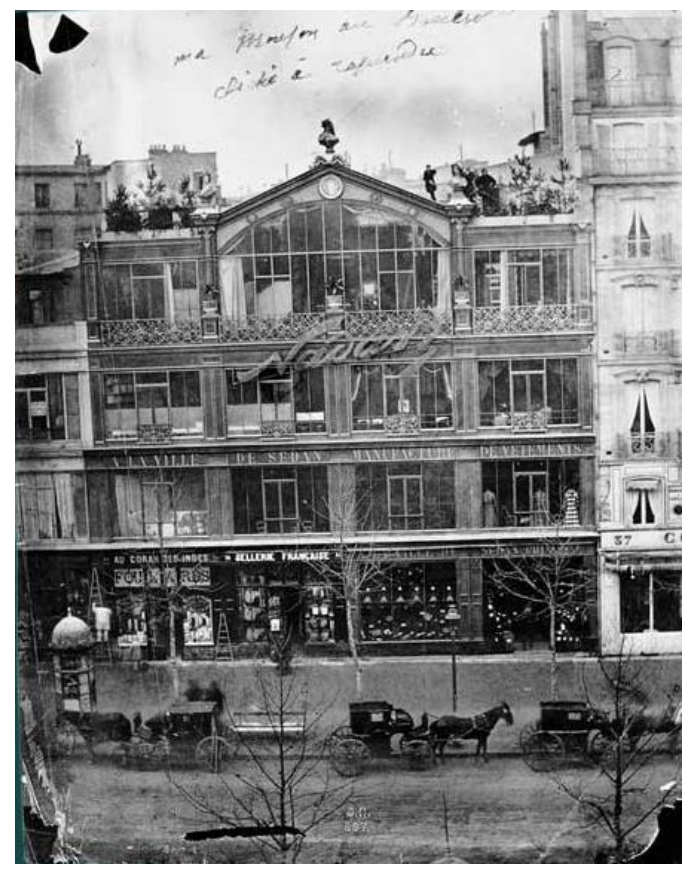

Fonte: Acervo do Getty Museum. https://commons.wikimedia.org/wiki/File:Nadar_atelier.jpg

É difícil dizer se era maior o interesse do fotógrafo por aqueles pintores ou o dos pintores pela fotografia; o que é certo, em todo caso, é que um dos móveis da reformulação pictórica foi a necessidade de redefinir sua essência e finalidades frente ao novo instrumento de apreensão mecânica da realidade (ARGAN, 1992, p. 75).

A essa primeira exposição, seguiram outras seis que, assim como a primeira, provocaram reações escandalizadas da crítica e do público, sendo as únicas exceções Théodore Duret, Louis Edmond Duranty e Émile Zola, este último amigo pessoal de Cézanne.

Embora não houvesse entre eles nenhuma convicção político ideológica, os artistas reunidos no Café Guerbois estabeleceram alguns pontos que deviam pautar sua arte: aversão à arte acadêmica oficial; orientação realista; preferência pela paisagem e natureza-morta; recusa do hábito de dispor e iluminar os modelos, e de começar desenhando o contorno para depois passar ao claro-escuro e à cor; preferência pelo trabalho ao ar livre, estudo das sombras coloridas e das relações entre cores

\footnotetext{
2 Félix Nadar, ou simplesmente Nadar, é o pseudônimo de Gaspard-Félix Tournachon (1820-1910), fotógrafo, caricaturista e jornalista francês.
} 
complementares (ARGAN, 1992). Apesar disso, não havia uma concordância entre todos os membros do grupo.

[...] uns propõem-se a representar da maneira mais imediata, com uma técnica rápida e sem retoques, a impressão luminosa e a transparência da atmosfera e da água com notas cromáticas puras, independentemente de qualquer gradação de chiaroscuro, evitando a emoção do tema. Para Cézanne e Dégas, a pesquisa histórica era tão importante quanto a da natureza (ARGAN, 1992, p. 76).

O que esses artistas tinham em comum era a reflexão sobre as características que devia ter sua arte, cuja técnica de conhecimento não poderia ser excluída do sistema cultural do mundo moderno, eminentemente científico. Segundo Argan, eles se questionavam sobre o caráter e a função possíveis da arte em uma época científica e também sobre como transformá-la para ser rigorosa como a técnica industrial, que depende da ciência.

O que se colocava era a relação entre as técnicas artísticas e as novas técnicas industriais, ou seja, a relação entre os valores e os significados das imagens produzidas pela pintura e pela fotografia. Desde sua invenção ${ }^{3}$, a fotografia, com o rápido progresso técnico que alcançou, permitindo reduzir os tempos de exposição e alcançar o máximo de precisão, se impôs como forma de reprodução e de expressão artística. O registro dos movimentos, por meio da técnica estroboscópica, a produção industrial de câmeras, cada vez mais sensíveis e as grandes transformações da psicologia da visão, determinadas pela utilização generalizada da fotografia, ao mesmo tempo fascinavam e ameaçavam os fazedores de arte, influenciando o direcionamento da pintura e o desenvolvimento das correntes artísticas. As encomendas - retratos, paisagens, ilustrações - feitas aos fotógrafos, aguçavam ainda mais a crise que atingia os pintores, transformando progressivamente o seu fazer artístico em atividade voltada para a elite. Essa situação pressionava no sentido da descoberta de novas formas de arte e, ao mesmo tempo, deixava no ar a discussão sobre a propriedade artística da fotografia e o destino da arte (ARGAN, 1992).

Para alguns, a fotografia nada mais era do que um produto inferior feito por uma máquina fria, para outros não era arte na medida em que apenas reproduzia objetos e cenas existentes. O Manifesto das Sete Artes, por exemplo, criado por Ricciotto Canudo, propunha que a Música, a Dança, a Pintura, a Escultura, o Teatro, a Literatura e o Cinema compusessem o topo de uma hierarquia artística. Embora a ordem proposta desagradasse a muitos, o que chamava mais a atenção era o fato de a fotografia ser desconsiderada enquanto manifestação artística.

A polêmica sobre os domínios próprios da fotografia e da pintura originou-se no discernimento sobre a natureza essencial da fotografia, ou seja, aquilo que a distinguia de todas as outras modalidades de imagens. Para Roland Barthes, o traço distintivo da fotografia como imagem, ao contrário da pintura, era que ela não era uma simples representação, um sucedâneo de um referente real ou imaginário (como a pintura), mas sim um certificado de existência, que ratificava a existência do referente.

[...] toda fotografia é um certificado de presença. Esse certificado é o gene novo que sua invenção introduziu na família das imagens. Toda foto é de alguma forma co-natural a seu referente [...] $\bigcirc$ referente da fotografia não é o mesmo que o dos outros sistemas de representação. Chamo de "referente

\footnotetext{
${ }^{3}$ A primeira fotografia reconhecida é uma imagem produzida em 1825, pelo francês Joseph Nicéphore Niépce, numa placa de estanho coberta com um derivado de petróleo fotossensível chamado Betume da Judeia. Posteriormente, Daguerre desenvolve um processo com vapor de mercúrio, que reduz o tempo de revelação de horas para minutos, e descreve seu processo à Academia de Ciências e Belas Artes, na França, e logo depois requer a patente do seu invento na Inglaterra. Em 1839, William Fox Talbot, que já efetua pesquisas com papéis fotossensíveis, ao tomar conhecimento dos avanços de Daguerre, apresenta seus trabalhos à Royal Society, procurando garantir os direitos sobre suas invenções.
} 
fotográfico", não a coisa facultativamente real a que remete uma imagem ou um signo, mas a coisa necessariamente real que foi colocada diante da objetiva, sem a qual não haveria fotografia (BARTHES, 1984, p. 17, 114-115).

Argan considerou insustentáveis as hipóteses de que "[...] a fotografia reproduz a realidade como ela é e a pintura a reproduz como se a vê", e de que "[...] a objetiva é um olho imparcial, e o olho humano é influenciado pelos sentimentos ou gostos da pessoa". No primeiro caso, pode-se dizer que, nessa época, a objetiva fotográfica apenas reproduzia o funcionamento do olho humano; no segundo, o fotógrafo imprimia à fotografia seu senso estético, por meio da escolha dos temas, disposição e iluminação dos objetos, enquadramento e enfoque. Assim, não tinha sentido questionar a fotografia enquanto manifestação artística, tratava-se de reconhecê-la como uma arte simplesmente distinta da pintura. $E$ para os que previam o fim da pintura a partir do advento da fotografia, Argan afirmou:

[...] a fotografia ajudou os pintores 'de visão' a conhecer sua verdadeira tradição, ajudou-os a separar, nas obras dos grandes mestres, os puros fatos de visão de outros componentes culturais que, até então, haviam impedido de avaliar essas obras do ponto de vista da pesquisa sobre a visão (1992, p. 81).

Nessa mesma linha de argumentação, que leva em conta a contribuição da fotografia para a pintura, Zamboni acrescentou:

[...] a pintura vem ocupar - por mais paradoxal que possa soar a frase - o exato lugar da pintura. A partir da consciência que a invenção da fotografia impinge a essa secular linguagem artística, a pintura assume a feição da complexidade que the cabe, em contraponto ao simples registro da realidade e da simples cópia da natureza (2007, p. s.n.).

Como reconheceu Paul Klee:

A fotografia foi inventada no momento certo, como advertência contra a visão materialista [...] De que vale a natureza, afinal? O que importa é a lei segundo a qual a natureza funciona e o modo como ela se revela a cada artista (1990, p. 215, 677).

Para aqueles que não consideravam a fotografia uma obra de arte, por entendê-la tão somente a partir de sua função reprodutiva, Walter Benjamim contra argumentou que "a obra de arte sempre foi reprodutível". Para ele, o que a fotografia trouxe de novo é que, pela primeira vez na história,

[...] a mão liberta-se das tarefas artísticas essenciais no processo que, daí em diante, são reservadas ao olho fixo sobre a objetiva. Como, todavia, o olho capta mais depressa do que a mão desenha, a partir de então, a reprodução de imagens pode se concretizar num ritmo tão acelerado que chega a seguir a própria cadência das palavras (1983, p. 6).

Embora Marcel Duchamp não fosse fotógrafo, Phillipe Dubois considerava sua arte como conceitualmente fotográfica, ou seja, trabalhada de acordo com a lógica do signo fisicamente ligado a seu referente antes de ser mimético. De acordo com ele, a obra de Duchamp,

[...] por mais complexa e múltipla que seja, aparece como a pedra de toque das relações entre fotografia e arte, como o lugar e o momento da reviravolta, em que se passa da ideia banal de que a foto vem libertar a pintura de seus vínculos da representação 'icônica', à outra ideia, segundo a qual a arte virá, a partir de então, extrair, das condições epistêmicas da fotografia, possibilidades de renovação de seus processos criativos e de suas apostas estéticas principais (DUBOIS, 2007, p. 258). 
Entre outros exemplos de trabalhos construídos com base na inscrição das 'sombras conduzidas', estão a série de perfis recortados em silhuetas, as 'rayografias', as que implicam a 'moldagem', as obtidas por 'decalque' ou por 'transporte', práticas que manifestavam o triunfo da lógica indiciária da arte de Duchamp, posteriormente desenvolvida por Man Ray.

Devido a seu acelerado desenvolvimento técnico, as técnicas de reprodução têm condições não somente de se dedicar as obras de arte do passado, modificando de modo profundo os seus meios de influência, como de conquistar seu lugar como formas originais de arte. Enquanto Benjamin considerava a reprodução manual, por mais perfeita que fosse, uma falsificação, afirmava que a reprodutibilidade técnica guardava certa autonomia em relação à obra original e justificava essa assertiva pela possibilidade que tem a fotografia de

[...] salientar aspetos do original que escapam ao olho e são passíveis de serem apreendidos por uma objetiva que se desloque livremente a fim de obter diversos ângulos de visão; graças a métodos como a ampliação ou a desaceleração, podem-se atingir realidades ignoradas pela visão natural (BENJAMIN, 1983, p. 7).

A reprodutibilidade técnica permitia ainda que a obra de arte fosse ao encontro do receptor sem acesso ao original. Apesar disso, Benjamin fez uma ressalva "[...] por mais perfeita que seja uma reprodução, falta-lhe sempre uma coisa: 'o aqui e agora' da obra de arte; a sua existência única no lugar onde se encontra" (1983, p. 7).

Esta afirmação conduziu à análise em torno da autenticidade de uma coisa que, para ele,

[...] é a soma de tudo o que desde a origem nela é transmissível, desde a sua duração material ao seu testemunho histórico. Uma vez que este testemunho assenta naquela duração, na reprodução ele acaba por vacilar, quando a primeira, a autenticidade, escapa ao homem e o mesmo sucede ao segundo; ao testemunho histórico da coisa. Apenas este, é certo; mas o que assim vacila, é exatamente a autoridade da coisa $(1983$, p.8).

Para Benjamin, na era da reprodutibilidade, "[...] o que se atrofia na obra de arte é a sua aura", entendida como um halo misterioso e inapreensível, fruto da união da magia, ou seja, do caráter transcendente, fugidio e inesgotável da obra de arte, com as características físico-químicas da imagem. Essa decadência seria resultado de um processo cujo significado, ultrapassando o domínio da arte, só podia ser compreendido pela emergência da nova sociedade, que reivindicava maior proximidade das coisas com as massas.

[...] as técnicas de reprodução libertam o objeto reproduzido do domínio da tradição. Multiplicando as cópias, elas transformam o evento produzido uma única vez em um fenômeno de massas. Permitindo ao objeto reproduzido oferecer-se à visão e à audição, em quaisquer circunstâncias, conferem-Ihe atualidade permanente (BENJAMIN, 1983, p. 8).

Segundo Argan, ao tornar visíveis inúmeras coisas que o olho humano não consegue captar, a câmera fotográfica, o microscópio e o telescópio permitiram que, por exemplo, o movimento das pernas de uma bailarina e as coisas infinitamente pequenas e grandes passassem a fazer parte da experiência visual, e, portanto, da competência do pintor. Nesse sentido, "a fotografia contribuiu para aumentar o interesse dos pintores pelo espetáculo social” (1992, p. 81).

Se for certo que o embate entre o eterno e o efêmero, as novas demandas sociais e o ingresso de novas mercadorias industriais no cotidiano contribuíram para transformar radicalmente a concepção de arte e 
sua função social, pode-se dizer que a velocidade, advinda do desenvolvimento da técnica, trouxe novas sensações e novas formas de percepção, como as que foram descritas por Victor Hugo, em um relato de sua primeira viagem de trem, em 1835

Um movimento magnífico, indescritível, que tem que ser experimentado diretamente. A rapidez é inacreditável. As flores à beira da estrada deixam de ser flores. E passam a ser manchas, ou melhor, listras vermelhas ou brancas. Não existem mais pontos, tudo é listrado. As espigas de trigo são grandes cabeleiras amarelas, as verduras são longas tranças verdes; cidades, campanários e árvores dançam e se mesclam furiosamente no horizonte, vez ou outra, uma sombra, uma forma, um espectro erguido, aparece e desaparece como clarões de raio ao lado da porta; é um guarda cancela de uniforme. Pessoas dizem no vagão; faltam três léguas, chegaremos em dez minutos (apud SCHAPIRO, 2002, p. 112).

\section{As características da luz e os mecanismos de percepção da cor}

Pode-se dizer ainda que a arte qualificada como abstrata teve origem no século XIX, período caracterizado, de um lado, por um grande corpo de arte representacional com vistas à ilustração e, de outro, pela emergência de uma série de pintores, que se voltam para as características da luz e dos mecanismos de percepção visual. De fato, ao longo desse século, teve lugar uma problematização crescente sobre o funcionamento do olhar: as diferentes teorias da percepção foram sendo assimiladas pelos pintores, impulsionando-os em direção a uma linguagem pictórica mais abstrata.

O que houve de novo foi que os fenômenos visuais passaram a ser estudados não apenas em si mesmos, em seus aspectos físicos, mas sobretudo como sensações moldadas pela percepção humana, que é histórica.

Até então, o que se tinha como certo era resultado das descobertas de Isaac Newton sobre o comportamento da luz. Descrevendo o experimentum crucis $(1666)^{4}$, o cientista inglês desafiou a crença herdada da Antiguidade de que a luz branca era indivisível. Utilizando um prisma transparente, comprovou que as cores, nomeadas por ele como rubeus, aurantius, flavus, viridis, caeruleus, indicus e violaceus (vermelho, alaranjado, amarelo, verde, azul, índigo e violeta), eram componentes da luz branca.

Em seu livro Opticks, publicado em 1704, o espaço de cores foi apresentado em forma de círculo, o disco de Newton. Esse disco, iluminado com luz branca e pintado com uma sequência de cores, quando em rotação resulta, para o observador, em um disco branco. Depois disso, todos os outros espaços de cores não mais incluiriam o branco e o preto entre as cores do espectro visível. O branco passaria a ser entendido como somatório de todas as cores e o preto como ausência de cor.

Muitas outras investigações em torno das características da luz e principalmente da percepção cromática humana foram levadas a cabo ao longo do século XVIII. Entre os cientistas dedicados ao tema estão Thomas Young, que sintetizou a teoria tricromática do sistema visual humano; Charles Bonnet que, em 1755, mencionou a existência de ressoadores de luz na retina; e Georg Christoph Lichtenberg que, em 1775, publicou um trabalho no qual apresentou as três cores-luzes primárias que o olho humano seria capaz de perceber: vermelho, amarelo e azul.

No último quarto desse século, ocorreram outras importantes contribuições para o conhecimento da percepção cromática humana. George Palmer, um especialista na fabricação de vidros coloridos, propôs, em 1777, a existência de três tipos de luzes que corresponderiam, respectivamente, a três tipos de partículas localizadas na retina. Em 1780, Jonh Elliot, depois de aventar que os órgãos sensoriais

\footnotetext{
${ }^{4}$ Experimentum crucis é uma expressão largamente usada no meio científico para designar uma experiência que demonstra cabalmente a legitimidade de determinada hipótese ou teoria. Supõe-se que tenha sido criada por Newton, já que aparece pela primeira vez na sua New Theory about Lights and Colors, publicada em 1672.
} 
humanos poderiam ser ativados mecanicamente na presença de estímulos apropriados, intuiu que o sistema visual humano não possuía ressoadores para todas as frequências existentes. Além disso, Gaspard Monge apresentou, em 1789, à Academia Real de Ciências de Paris, o fenômeno que chamou de sombras coloridas. Conhecido mais tarde por lei das complementares, o fenômeno trata da modificação de uma cor em função da presença de sua complementar.

Embora todos os conceitos para a elaboração da teoria tricromática estivessem disponíveis no final do século XVIII, sua elaboração definitiva foi iniciada somente, a partir de 1801. A teoria de Thomas Young foi apresentada, de forma sólida, em 1817, em um artigo denominado Chromatics. Além de concluir que diferentes comprimentos de onda correspondiam a diferentes matizes - os mais curtos em violeta e os mais longos em vermelho -, o pesquisador demonstrou, com precisão, um mapa de distribuição dos matizes do espectro visível.

Por volta dessa época, o poeta e escritor alemão Johann Wolfgang Von Goethe se apaixonou pelas cores, passando a se dedicar à obra Teoria das cores que, segundo ele, poria abaixo a teoria de Newton (figura 2). Segundo Gianotti (1998), o que estava por trás desse desafio era o confronto entre dois modos distintos de pensar a natureza. O idealismo alemão, que recusava a ótica mecanicista, interpretava tanto a natureza quanto a arte a partir da ideia de organismo, de uma finalidade interna. Nesse caso, a cor não podia ser simplesmente causada pela luz, devia ser pensada na sua relação com o órgão específico, como explicou o próprio Goethe:

[...] não há nada exterior a nós que não esteja ao mesmo tempo em nós, assim como o mundo exterior, o olho possui suas cores. Somente por meio dessa ciência pode-se separar nitidamente o objetivo do subjetivo. Portanto, comecei a tratar apenas das cores pertencentes ao olho, a fim de que distingamos bem se as cores realmente existem no exterior ou se é apenas uma cor aparente, que o exterior engendrou por si mesmo (apud GIANNOTTI, 1998, p. 173).

Figura 2: Roda cromática de Goethe, extraída da obra Teoria das cores, publicada em 1810.

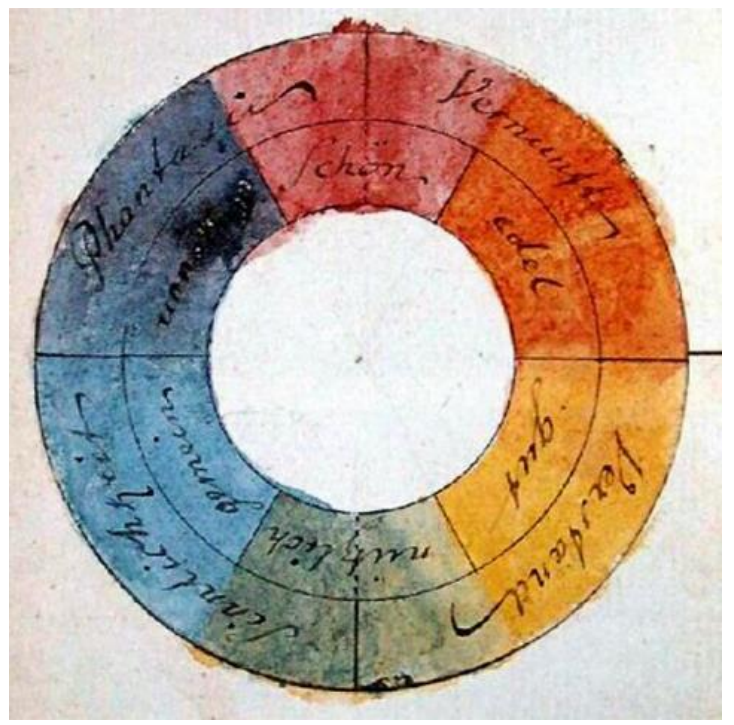

Fonte: https://commons.wikimedia.org/wiki/File:Goethe, Farbenkreis zur Symbolisierung des menschlichen Geistesund Seelenlebens, 1809.jpg

Para Goethe, o olhar é crítico e, portanto, as cores deviam ser interpretadas duplamente, como ação (tat) e como paixão (leiden) da luz. Era a atividade da retina que diferenciava o fenômeno cromático: se fosse maior, ter-se-iam cores subjetivas (fisiológicas); se sofresse um estímulo externo por mais tempo, sua ação seria menor, e as cores seriam consideradas mais objetivas (químicas). A partir dessa 
premissa, Goethe chamou a atenção para certos aspectos sobre fisiologia e psicologia da cor que Newton havia desconsiderado.

Observando a retenção das cores na retina, a tendência do olho humano em ver nas bordas de uma cor complementar, notou que objetos brancos sempre parecem maiores do que os objetos com ausência de luz. Além disso, reinterpretou as cores e as renomeou de púrpura, amarelo e azul claro, aproximandose, com precisão, das cores magenta, amarelo e ciano, utilizadas atualmente em impressões industriais. Durante suas investigações, preocupou-se ainda com o efeito das diferentes cores sobre seres humanos, ou com o que chamou de "efeito sensorial-moral das cores".

No entanto, devido ao enorme prestígio de Newton e à falta de um método científico que melhor embasasse suas informações, a obra de Goethe, Esboço de uma teoria das cores $(1810)^{5}$, mostrou-se complexa demais para os leigos e não sensibilizou a comunidade científica da época. ${ }^{6}$ Apesar disso, o esforço de ordenar e combinar os fenômenos cromáticos, para entender os princípios que os regem e como essa ordenação leva a uma diferenciação em termos estéticos, sensibilizou artistas da época, entre os quais William Turner, cujo quadro Light and Color, de 1843, foi pintado após a leitura dos escritos de Goethe (figura 3).

Figura 3: Light and Color, William Turner, 1843

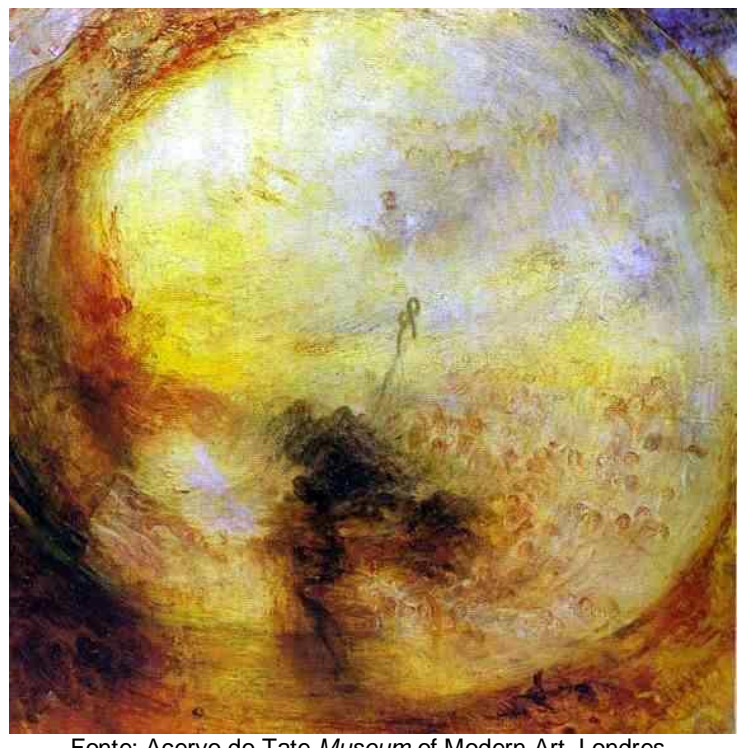

https://commons.wikimedia.org/wiki/File:William Turner, Lightand Colour (Goethe\%27s Theory).JPG

As especulações em torno da luz e das cores foram retomadas pelo químico francês Michel Eugène Chevreul que, com a obra Le traité des couleurs: de la loi du contraste simultané des couleurs, publicada em 1839, estabeleceu definitivamente a lei do contraste simultâneo, que havia sido sugerida por Leonardo da Vinci e, posteriormente, mencionada por Goethe. Baseado em estudos de contraste e harmonia, Chevreul criou um sistema de cores com base um círculo cromático (figura 4) composto de 72 matizes distribuídos radialmente, sendo que para cada matiz poderia haver variação da saturação (eixo $\mathrm{x}$ ), e variação do brilho (eixo $\mathrm{y}$ ).

Figura 4: Círculo cromático de Michel Eugène Chevreul, 1839

\footnotetext{
5 Para alguns autores, a tradução mais correta do título da obra é Esboço para uma doutrina das cores.

${ }^{6}$ Atualmente, o estudo da teoria das cores divide-se em três matérias com as mesmas características propostas por Goethe: ótica física, ótica fisiológica e ótica físico-química.
} 


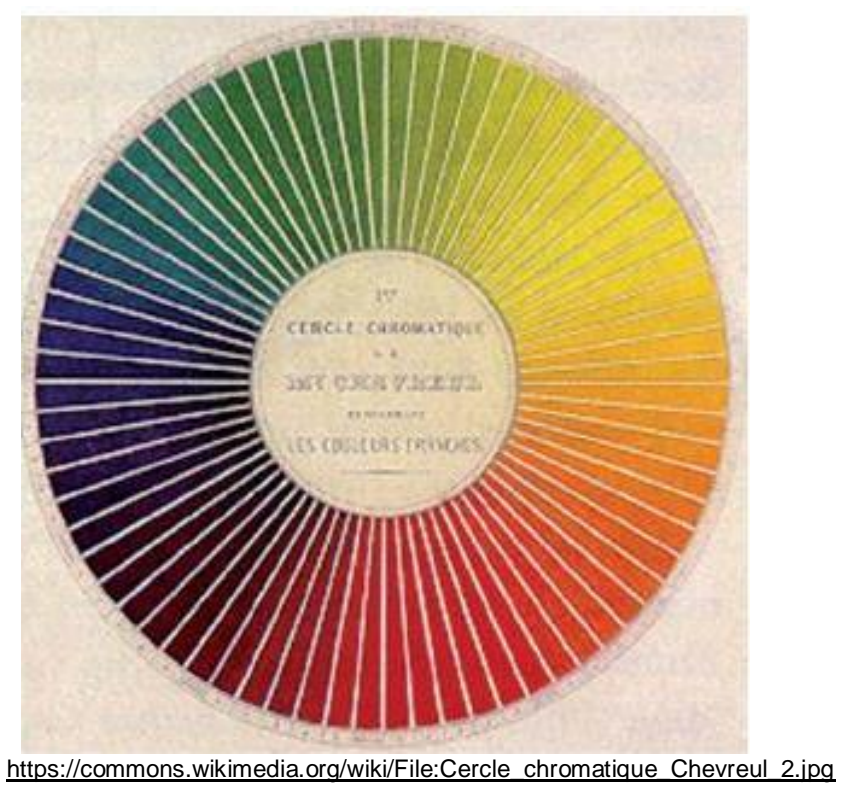

Em 1853 o matemático polonês Hermann Gunter Grassmann (1809-1877) publicou uma teoria da mistura de cores, que incluía um conceito fundamental para os futuros sistemas a serem concebidos: a complementaridade das cores, por meio da qual cada ponto em um círculo de cores tem, dentro deste, um complementar.

Nesse mesmo período, emergiram os fundamentos básicos para a hipótese, formulada por Hermann von Helmholtz e James Clerk Maxwell segundo a qual, uma vez que a luz chega aos olhos, existem três classes de fotorreceptores cones responsáveis pela visão de cores. Helmholtz foi o introdutor de um conceito fundamental para os espaços de cores criados no século XX: a demonstração das diferenças nas misturas de cores provenientes de luz (cores-luzes) e de cores provenientes de pigmentos (corespigmentos). ${ }^{7}$

Em 1892, contrapondo-se a Helmholtz e Maxwell, o fisiologista alemão Karl Ewald Konstantin Hering propôs a teoria de oposição das cores, segundo a qual a experiência cromática resulta da análise, pelo sistema nervoso, das cores em pares opostos. O verde opondo-se ao vermelho, o azul ao amarelo e o laranja ao violeta. Em 1905, foi desenvolvido pelo artista e educador Albert Henry, o sistema Munsell de ordenamento cromático (figura 5), que passou a ser utilizado tanto pelas indústrias como na elaboração de testes para avaliação de deficiências na visão de cores.

Figura 5: Sistema de ordenamento cromático, Albert Henry Munsell, 1905

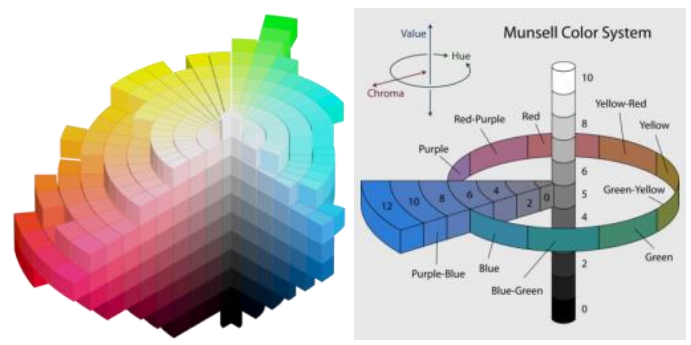

Fontes: https://commons.wikimedia.org/wiki/File:Munsell 1929 color solid cylindrical coordinates.png https://commons.wikimedia.org/wiki/File:Munsell-system.svg

\footnotetext{
7 Esse conceito originou a terminologia: mistura aditiva para as cores-luzes e mistura subtrativa para as corespigmentos.
} 
Se a partir do século XVIII, a cor passou a ser um elemento fundamental para a diferenciação espacial, como instrumento capaz de ativar a percepção e conferir uma sensação de profundidade, foram os trabalhos de Goethe e Chevreul que, resultando em tentativas de basear a pintura nas leis científicas da visão, exerceram influência direta sobre a arte moderna.

Enquanto Goethe colocou em evidência um vocabulário abstrato que passou a alimentar a imaginação de um grande número de artistas, as pesquisas de Chevreul provocaram uma espécie de genealogia da abstração que, da dissolução das formas dos impressionistas passou pelos reconstrução formal proposta pelos neoimpressionistas até chegar às formas mais puras do orfismo.

Além disso, depois das obras de Goethe e Chevreul, e dos novos caminhos abertos sobre a percepção humana dos fenômenos cromáticos, vários pintores passaram a se dedicar aos estudos da cor (figuras 6 e 7$)$.

Figura 6: Diagrama cromático de Johannes Itten ${ }^{8}, 1921$
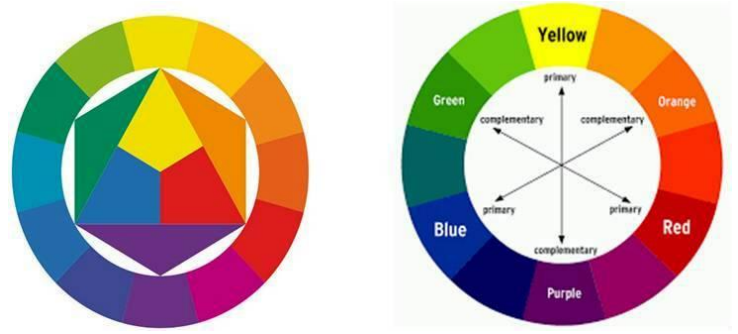

Fonte:

https://commons.wikimedia.org/wiki/File:Farbkreis Itten 1961.png

Figura 7: Estudo de cores de Paul Klee, 1931

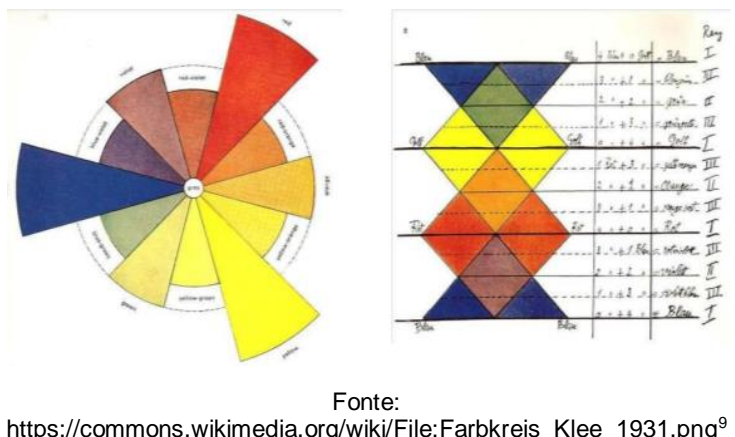

\section{A psicologia da percepção - Gestalt}

Ainda no século XIX os estudos sobre a percepção humana estenderam-se ao campo da psicologia. Baseando-se nos conceitos estéticos explicitados na Crítica do Juízo (1790), de Emmanuel Kant, e na quebra de tabus da psicologia clássica, que defendiam a teoria atomista da percepção, o psicólogo austríaco Christian von Ehrenfels lançou, em 1890, as sementes do que viria ser a Psicologia da Gestalt, ou Psicologia da Boa Forma. Ehrenfels atribuiu o termo Gestalt a um conjunto complexo de dados que necessitavam mais do que uma experiência sensorial e imediata para serem percebidos. Defendia que para haver apreensão de um objeto era necessário que os seus componentes fossem percebidos como um todo.

\footnotetext{
8 Itten escreveu sobre o tema: A Arte da Cor: a experiência subjetiva e objetiva da cor, publicado em alemão em 1961. Posteriormente, com organização de Farber Birren e tradução de Ernst Van Hagen, foi publicado The elements of color: a treatise on the color system, baseado no seu livro anterior.

${ }^{9}$ Os originais das lições de arte de Paul Klee na Bauhaus encontram-se no Zentrum Paul Klee em Berna, Suíça.
} 
$\mathrm{Na}$ psicologia clássica, a percepção da forma, ou percepção visual, seria resultado da soma de sensações isoladas: ao incidir na retina, a luz iniciava uma mensagem dirigida ao cérebro dando origem às sensações visuais. Nesse caso, a forma se daria, posteriormente, por um processo de associação dessas sensações. Esse processo, por sua vez, era explicado a partir da experiência do indivíduo, que, pelo contato sucessivo com objetos idênticos, aprendia a associar os estímulos luminosos que deles provinham.

No entanto, esta teoria não apresentou explicações para determinados fenômenos visuais, entre os quais a ilusão de ótica. Diante da espiral de $\operatorname{Fraser}^{10}$ (figura 8), os observadores, independentemente de sua experiência artística, têm a ilusão de que é composta por círculos paralelos concêntricos. Em outro exemplo, conhecido por ilusão de Zöllner (figura 9) ${ }^{11}$, o paralelismo entre as linhas pretas maiores não é reconhecido pelos observadores.

Figura 8: Espiral de Fraser

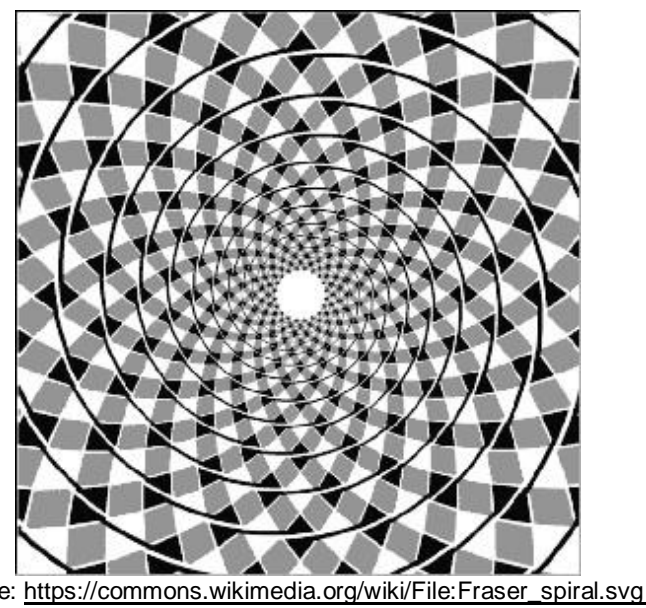

Figura 9: Ilusão de Zöllner

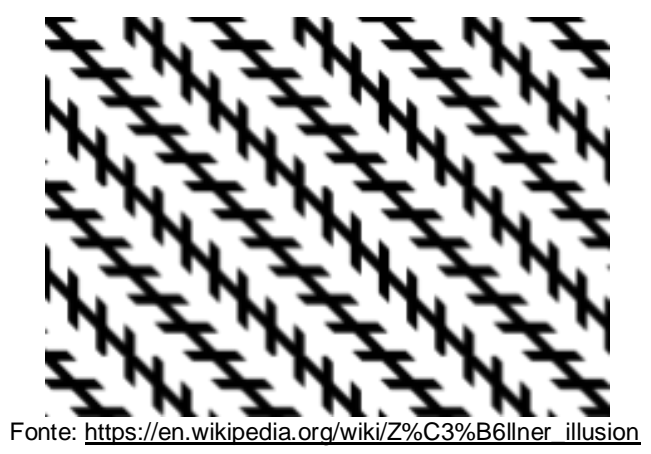

Ainda no século XVI, Leonardo da Vinci, percebendo a complexidade da visão, mostrou-se capaz de fazer uso da ambiguidade dos fenômenos óticos para produzir, por exemplo, o quadro Monalisa (15031506), uma de suas obras-primas.

Valendo-se dos pontos de fuga, da variação dos tamanhos dos objetos em relação à distância e de uma série de artifícios, tais como claro-escuro, esfumaçamento das cores etc., a perspectiva linear resulta em um "sofisticado trabalho de ilusionismo", conforme definiu Eduardo Neiva Junior. Ao comentar a discrepância entre a percepção humana e a perspectiva linear, o autor afirma que esse fenômeno devese ao fato de o olhar humano perceber as imagens "[...] de modo ligeiramente esférico, já que sua visão

10 Descrita pelo psicólogo inglês James Fraser, em 1908.

${ }^{11} \mathrm{O}$ astrônomo e físico alemão Johann Karl Friedrich Zöllner descreveu o fenômeno de ilusão de ótica em 1860. 
não ocorre não a partir da projeção em uma tela estendida e sim a partir de projeções em cada um dos dois globos oculares". (1986, p. 36)

A constatação dessas distorções visuais estimulou, no início do século $X X$, o desenvolvimento de pesquisas no campo da psicologia, as quais contaram com a adesão de Curt Koffka, Wolfgang Köhler, e Max Werteimer, responsáveis pelo desenvolvimento das Leis da Gestalt.

[...] para que exista uma percepção estética, é necessário não ver os objetos como significado, mas como forma, todos estruturados como resultados de relações [...] Que se possa sentir o prazer de uma inscrição somente pela harmonia da caligrafia, independente do significado da palavra (KOFFKA, 1975, p. 47).

Fundamentados em exaustivas experiências direcionadas ao campo da percepção visual e na avaliação de um conjunto de obras de arte, os estudos da Gestalt buscaram resolver questiona- mentos clássicos da avaliação estética - como a razão de algumas formas agradarem mais do que outras; encontrar recursos para um tratamento mais racional do fenômeno artístico e compreender a relação entre o produtor e o apreciador da arte.

De acordo com esses estudos, o homem não enxerga partes isoladas, mas relações e, para sua percepção, que é resultado de uma sensação global, as partes são inseparáveis do todo. Todo processo consciente, toda forma psicologicamente percebida, está relacionada com forças integradoras do processo fisiológico cerebral. A explicação sobre a origem dessas forças está na existência, no sistema nervoso central, de um dinamismo autorregulador que, em busca de sua própria estabilidade, tende a organizar as formas em 'todos' coerentes e unificados.

Buscando compreender como eram atingidos certos efeitos pictóricos, os estudos conduziram à conclusão de que a percepção resulta da união entre as características sensíveis da forma, inerentes ao objeto, e as características formais, que incluem as impressões humanas sobre a matéria, estas, por sua vez, impregnadas dos ideais e das visões de mundo. Com isso, a visão, longe de ser um registro mecânico de elementos sensoriais, passou a ser vista como um atributo crítico, uma apreensão verdadeiramente criadora da realidade, e, para Rudolf Arnheim "[...] imaginativa, inventiva, perspicaz $e$ bela" (1997, s.n.).

Questionando o subjetivismo e o relativismo enraizado nas teorias artísticas dos séculos anteriores, os defensores da Gestalt viam o ato de olhar o mundo a partir da existência de uma interação entre as propriedades do objeto e a natureza do sujeito que as observava. Isso significava depositar confiança na validade objetiva da arte. Eles pretendiam, por meio do estabelecimento de princípios básicos que regem a percepção visual, desmontar noções estereotipadas de gosto e arte, argumentando contra afirmações do tipo "gosto não se discute" ou "arte não se ensina".

Há algo que transcende a um exclusivo gosto pessoal ou a um gosto na dependência de um momento histórico. Só em função de alguma constante pode-se explicar que o homem realize e perceba a beleza, quer seja através de uma escultura primitiva, uma estátua grega ou de uma composição de nossos dias (FRACAROLLI, 1982, p. 27).

Tratava-se então de compreender a 'agradabilidade visual' ao ponto de transformá-la em uma ferramenta útil, que permitisse trabalhar com o senso comum e a possibilidade de universalização de julgamento quando da apreensão do objeto.

Segundo as sistematizações da teoria da Gestalt, o observador identifica e reconstrói mentalmente, com mais facilidade, as formas mais simples e regulares, seguindo os princípios de: proximidade, igualdade, 
fechamento, identidade, densidade, pregnância, equilíbrio e concisão. Para Koffka, a arte se funda sobre o princípio da pregnância. Na formação de imagens, o equilíbrio, a clareza, a unidade e a simplicidade representam, para o homem, uma necessidade e, por isso, ele procura e reconhece esses aspectos como indispensáveis nas obras de arte. Segundo a teoria da Gestalt,

[...] existe uma correspondência entre a ordem que o artista escolhe para distribuir os elementos de sua composição e os padrões desenvolvidos pelo sistema nervoso. São as leis de proximidade e semelhança que, inconscientemente, guiam o artista na sua atividade, da mesma maneira é levado pelo princípio da boa continuidade, que dá sequência e movimento a suas obras (FRACAROLLI, 1982, p. 29-30).

De acordo com Herbert Read, o artista trabalha para uma unidade que surge progressivamente de sua percepção e manipulação das qualidades materiais, ao passo que os apreciadores do resultado parte da unidade para depois tomarem consciência das qualidades isoladas que se juntam para produzi-lo. Segundo o autor, existe uma "significação biológica da arte", ou seja, admiramos uma obra de arte porque ela possui os valores de ordem e unidade necessárias que são captadas pela percepção, ou seja, a constituição cerebral apresenta uma relação biológica com as formas existentes.

Para o biólogo Paul Weiss, existe uma relação direta entre os padrões de beleza encontrados na natureza e o reconhecimento das mesmas pela percepção humana.

[...] a beleza sugere mais que uma simples ordenação, especifica um tipo particular de ordenação. Postula a ordem compatível com a singularidade [...] e a natureza não é caótica e atomizada. Seus padrões são primários e inerentes e a ordem fundamental de beleza é aparente. E a mente humana somente pode perceber esta beleza porque ela própria é parte e parcela desta ordem (WEISS, 1960, s.n.).

Wilhelm Worringer, por sua vez, admitiu que o impulso de satisfação culmina na beleza do orgânico; enquanto o impulso abstracionista encontra a sua felicidade na beleza inorgânica, no que é regido por leis e por necessidades abstratas.

Por meio da relação entre a psicologia da forma e o fenômeno artístico foi possível compreender que a força de organização própria do homem, que é a base rudimentar de toda a percepção, constitui também o alicerce da percepção estética.

Apesar de terem explorado os campos da percepção cromática, é possível dizer que os estudos gestálticos foram mais desenvolvidos no campo da forma em si. Isso se justifica talvez por ser este um meio de identificação melhor do que a cor, pois, além de oferecer mais tipos de diferença qualitativa, suas características distintivas são muito mais resistentes às variações do ambiente.

Embora a assim chamada constância da forma não seja de maneira alguma tão segura quanto se considera, notamos que as pessoas são extraordinariamente capazes de reconhecer um objeto, mesmo que o ângulo do qual elas o percebem possa apresentar uma projeção completamente diferente do mesmo [...] a configuração é quase inteiramente insensível às mudanças de claridade ou cor do ambiente, enquanto a cor local dos objetos é mais vulnerável nesse aspecto (ARNHEIM, 1997, p. 324).

A indeterminação da cor e a necessidade de reforçar o caráter científico dos experimentos artísticos provocaram uma revalorização da forma. Se a experiência da cor era identificada com o afeto ou a emoção e, se a emoção era vista como não sendo um produto da mente ativamente organizadora, foi à 
forma que se voltaram principalmente as categorias de percepção cunhadas pela Gestalt. Isso fica claro nas palavras de Matisse que enfatizam a importância da forma em detrimento da cor:

Se o desenho pertence ao espírito e a cor aos sentidos, deve-se desenhar primeiro para cultivar o espírito e depois ser capaz de conduzir, pela cor, ao caminho do espiritual (apud CHIPP, 1999, p. 137) ${ }^{12}$

Talvez por esse apelo ao caráter espiritual da arte ou pela necessidade de imprimir uma nova dinâmica à obra pictórica, a definição das formas pelo desenho, ou as limitações impostas por uma certa rigidez das linhas de contorno, cedia lugar à exploração das potencialidades da luz expressas pela cor.

\section{Do Impressionismo à arte abstrata}

Luz e movimento, obtidos por meio de pinceladas soltas, tornaram-se os principais elementos da pintura impressionista, feita geralmente ao ar livre para que o artista pudesse capturar melhor as variações de cor (figura 10). Muitas vezes um mesmo tema era pintado em diferentes horas do dia de modo a reter os múltiplos matizes cromáticos produzidos pelas variações da luz natural.

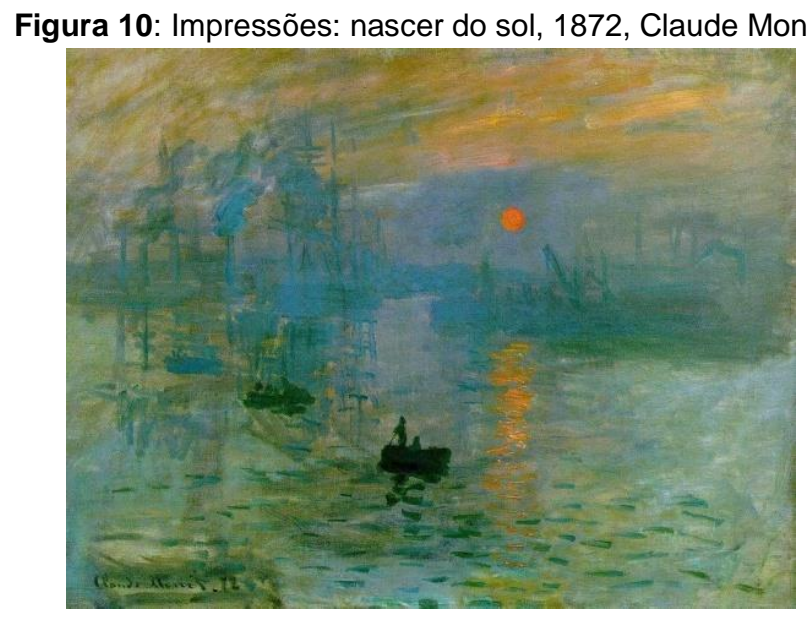

Fonte: Acervo do Musée Marmottan Monet, Paris

https://pt.wikipedia.org/wiki/Impressionismo\#/media/File:Claude Monet, Impression, soleil levant, 1872.jpg

As formas dissolvidas nas manchas de cor, que caracterizaram o Impressionismo, passaram a ser tratadas de maneira mais sistematizada e rigorosa no Neoimpressionismo. A técnica do pontilhismo, desenvolvida principalmente por Georges Seurat, Paul Signac e Camille Pissarro, consistiu em uma justaposição de pequenas manchas ou pontos, de cor pura, a serem recompostas a certa distância pelo olhar do observador. Baseadas na lei das complementares ${ }^{13}$, as dimensões dessas manchas coloridas eram determinadas de acordo com o tamanho da tela.

Apoiado na lei das cores complementares, a pintura pontilhista (figura 11) orientava-se a partir da divisão das cores em seus componentes fundamentais. As ligeiras pinceladas regulares de cores puras, que cobriam a tela, eram recompostas pelo olhar do observador, recuperando-se então a unidade formal. A sensação de vibração e luminosidade decorria da mistura ótica obtida pelos pequenos pontos de cor, de tamanho uniforme, que nunca se fundiam, mas que reagiam uns aos outros em função do olhar à distância.

12 MATISSE, Henri. A facilidade de pintar. Carta a Henry Clifford, Diretor do Museu de Arte da Filadélfia. Veneza, 14 de fevereiro de 1948.

${ }^{13}$ Ao perceber que havia influência recíproca entre as cores, Michel Eugène Chevreul formulou o que chamou de "lei do contraste simultâneo das cores". 
Figura 11: A baía, 1906, Paul Signac.

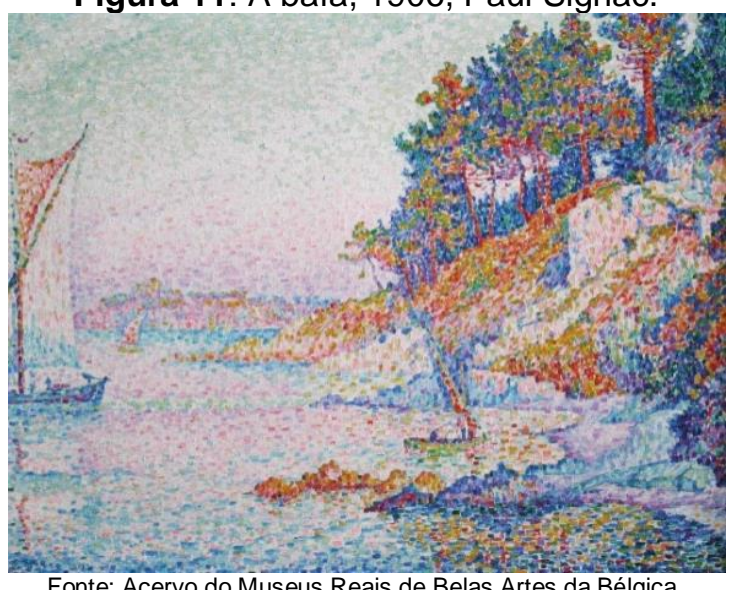

Fonte: Acervo do Museus Reais de Belas Artes da Bélgica.

https://pt.wikipedia.org/wiki/Pontilhismo\#/media/File:Signac - La Calanque edit.jpg

Em lugar do naturalismo e da preocupação com os efeitos momentâneos de luz, fundamentais para os impressionistas, estes artistas expunham figuras de corte geométrico, que se apresentavam sobre um plano rigorosamente construído a partir de eixos horizontais e verticais. Os intervalos calculados entre uma figura e outra, as sombras formando ângulos retos e as superfícies pontilhadas serviam para atestar a coerência com um programa teórico apoiado nos avanços científicos da época.

Seguindo o campo da exploração cromática, surgiu, em 1912, o Orfismo (figura 12), movimento nomeado pelo escritor e crítico de arte francês Guillaume Apollinaire, que pretendia conferir um novo lirismo ao cubismo de Pablo Picasso, Georges Braque e Juan Gris. Para os membros do grupo de Puteaux ${ }^{14}$ Robert Delaunay, Fernand Léger, Francis Picabia, Marcel Duchamp e Frank Kupka, que perseguiam uma suposta analogia entre a música e a abstração pura, a cor seria o principal meio de expressão artística.

Figura 12: Janelas sobre a cidade, 1912, Robert Delaunay.

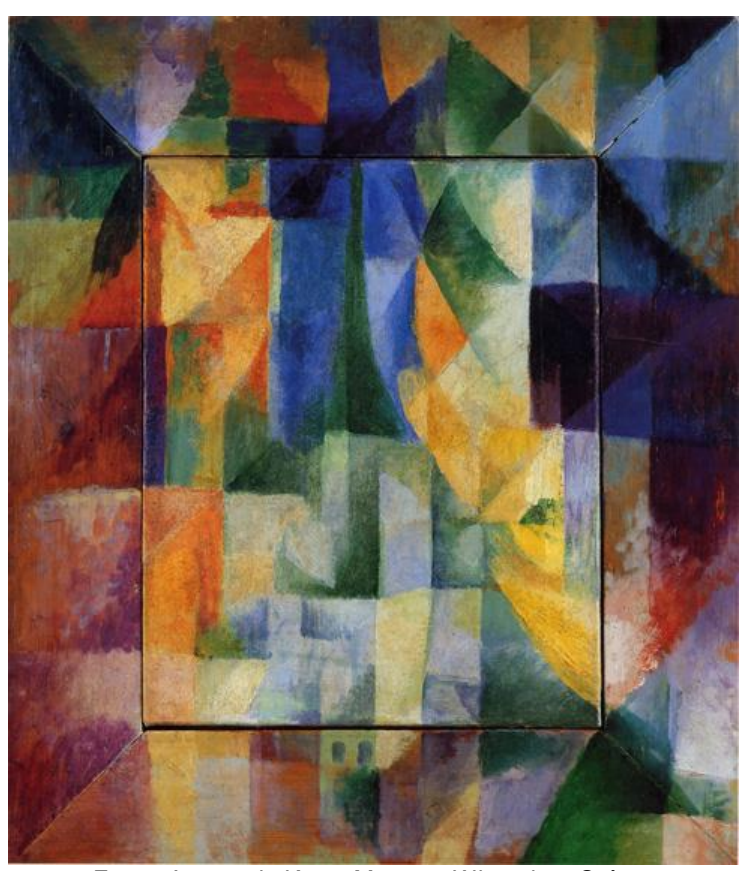

https://www.google.com.br/search?q=orfismo+delaunay\&tbm=isch\&source=Int\&tbs=sur:f\&sa=X\&ved=0ahUKEwj629ju4eXaAhXGx5

14 Região situada nos arredores de Paris onde, em 1911, formou-se um grupo de artistas e críticos europeus associado ao Cubismo, ou mais precisamente ao Orfismo. 
Essa trajetória com vistas à construção da arte abstrata pode ainda ter partido de Édouard Manet, com a reivindicação do plano da tela e a recusa à ilusão da profundidade; enveredado pelas séries pictóricas de Claude Monet, com a criação da sensação visual a partir da descontinuidade do tempo e da substituição da estabilidade pela incompletude; percorrido a proposta analítica da pintura de Paul Cézanne, fonte do cubismo; acompanhado o fauvismo em sua reivindicação da cor, até chegar à abstração ou à depuração da tela pautada na exploração essencial de seus elementos constituintes: plano, linha e cor.

As ideias sobre arte, que pairavam no período, negavam a ênfase na imitação e sublinhavam o papel da imaginação e do inconsciente como fatores criativos essenciais, fazendo com que muitos artistas começassem a aceitar as novas liberdades e responsabilidades implícitas nessa atitude. Ao declarar, em 1890, que uma imagem, antes de ser um cavalo de batalha, um nu, uma anedota ou outros enfeites, é essencialmente uma superfície plana coberta de cores reunidas numa certa ordem, Maurice Denis estabeleceu como princípio da abstração o distanciamento dos laços entre o quadro e seu referente, reafirmando a autonomia da criação. Antes de acolher 'um cavalo de batalha ou um nu', o quadro era o suporte em que se inseria o processo de gênese da materialidade da obra, princípio da autocriação, que parecia justificar a existência dos elementos constitutivos da obra sem apelo a qualquer instância supostamente exterior.

\section{Considerações Finais}

Mesmo sem fazer referência ao discurso dominante do modernismo voltado à purificação e depuração da prática artística, o processo de separação entre o objeto real e a arte abriu caminho, sob uma complexa via de influência das teorias da percepção, para a emergência de uma primeira forma de abstração, na qual a consciência das relações da pintura com seus próprios meios constitutivos tornaram-se a base principal para a constituição da obra. Tratava-se de uma nova relação plural entre a arte e o mundo da imagem criada e processada pelas ideias do artista no domínio da inventividade.

Para Ângela Maria Grando Bezerra (2012), esse processo pode fazer parte de uma lógica perceptiva da modernidade a qual se estrutura deslocando-se. Concordando com Georges Didi-Huberman, a autora considera que os signos abstratos se fazem perceber no pensamento associativo, possuindo assim valor de passagem. E, para reforçar essa análise, busca apoio no texto de Michel Foucault que, opondo-se à historiografia que apela às noções de continuidade e linearidade, retomou alguns princípios imbricados no conceito de origem. Segundo esse pensador, a experiência de expansão da genealogia é "cinza", pois leva a muitas interrogações e à densidade de relações que o artista desenvolve com seu campo cultural e com outros campos que ele reencontra em uma possível procura do dinamismo e da autenticidade de sua obra. Essa indeterminação ganha relevância crescente com o nascimento do "sujeito experimentalista", visceralmente ligado às mutações geradas pela complexidade da vida urbana nas sociedades capitalistas ocidentais de fins do século XIX.

Ao analisar a pintura de Manet, Foucault (2004) observou que, diferentemente do Renascimento, quando a pintura tentava conformar a ilusão das três dimensões por meio do recurso à iluminação posta no interior do quadro e da proposição de grandes linhas oblíquas prontas a disfarçar os ângulos retos, os pintores passavam a expor 0 antes negado ou escondido: a materialidade da tela, seu caráter bidimensional. Mais ainda, subvertiam a tentativa, também peculiar à pintura anterior, de ocultar a materialidade do quadro pela delimitação do lugar ideal do espectador.

E Manet reinventa (ou talvez inventa?) o quadro-objeto, o quadro como materialidade, o quadro como coisa colorida que uma luz externa vem iluminar e diante do qual, ou ao redor do qual, vem girar o espectador. Essa invenção do quadro-objeto, essa reinserção da materialidade da tela naquilo que é representado, é isso, creio eu, que está no cerne da grande modificação trazida 
por Manet à pintura, e é nesse sentido que se pode dizer que Manet abalou, para além de tudo que podia preparar o Impressionismo, tudo o que era fundamental na pintura ocidental após o Quattrocento [...] Manet certamente não inventou a pintura não representativa, pois tudo em Manet é representativo, mas ele fez agir na representação os elementos materiais fundamentais da tela, ele estava inventando o quadro-objeto, a pintura-objeto, e estava aí, sem dúvida, a condição fundamental para que um dia finalmente nós nos livremos da própria representação e que deixemos agir o espaço com suas propriedades puras e simples, suas propriedades materiais em si mesmas (FOUCAULT, 2010, p. 262 e 284).

Essa ousada e radical ruptura com a pintura tradicional, o abandono de seu jogo de esquiva e a invenção do "quadro-objeto", ao invés do "quadro-espetáculo", acabaram por conduzir à fundação do espaço artístico moderno que, como produto do contato reflexivo, instável e experimental entre o olho e o mundo, redimensionou, no século XX, o paradigma autoral nas artes visuais, criando espaço para o abstrato da pintura de Piet Mondrian, Wassily Kandinsky e Kasimir Malevich.

Embora a mimese, como imitação ou duplicação do mundo visível e da natureza, tenha sido um método básico de experimentação humana ao longo da história, ela deixava de fazer sentido para aqueles que desejavam ir além. Não se tratava de subestimar a natureza enquanto fonte inesgotável de elementos visuais, mas sim de vê-la com um o olhar crítico, capaz de perceber os seus padrões de organização intrínsecos, de desvendá-la para além do que ela abertamente mostrava.

Além de libertar os artistas da tarefa de imitar a natureza e os objetos, com o desenvolvimento da fotografia e as novas teorias sobre a percepção humana, a arte passou a envolver mais os espectadores, fazendo com que passassem a ter uma postura mais ativa. Abriu também novos caminhos para o ensino que, ao invés de se voltar para os reconhecidos talentos, tornou-se mais aberta para todos e, sobretudo, para as novas possibilidades da experimentação teórica e da manipulação dos diferentes materiais capazes de concretizá-la.

\section{Referências}

ARGAN, Giulio Carlo. Arte Moderna: do iluminismo aos movimentos contemporâneos. Tradução de Denise Bottmann e Frederico Carotti. São Paulo: Companhia das Letras, 1992.

ARNHEIM, Rudolf. Arte e percepção visual: uma psicologia da visão criadora. $11^{\underline{a}}$ ed. São Paulo: Pioneira; Edusp, 1997.

BARTHES, Roland. (1979). A câmara clara. Rio de Janeiro: Nova Fronteira, 1984.

BENJAMIN, Walter (1936). A obra de arte na era de sua reprodutibilidade técnica in Textos escolhidos. Col. Os Pensadores. $2^{\underline{a}}$ ed. São Paulo: Abril Cultural, 1983.

BEZERRA, Ângela Maria Grando. Redes da abstração: uma dinâmica da arte moderna. Anais do XXXII Colóquio do Comitê Brasileiro de História da Arte (CBHA). Brasília: UnB, 2012, p. 1807.

CHIPP, Herschel B. Teorias da Arte Moderna. São Paulo, Martins Pena, 1999.

DENIS, Maurice. Théories 1890-1910: du symbolisme et de Gauguin vers un nouvel ordre classique. $4^{\text {a }}$ ed. Paris: L. Rouart et J. Watelin Ed., 1920.

DUBOIS, Philippe. 0 ato fotográfico e outros ensaios. Tradução Marina Appenzeller. Campinas: Papirus, 2007. 
FOUCAULT, Michael. A pintura de Manet. Tradução de Rodolfo Eduardo Scachetti. Visualidades, Goiânia v.9 n.1 jul-dez 2010. www.revistas.ufg.br/index.php/VISUAL/article/download/.../10944

FRACAROLLI, Caetano. A percepção da forma e sua relação com o fenômeno artístico: o problema visto através da Gestalt (psicologia da forma). São Paulo: Fausp, 1982.

GIANNOTTI, Marco Garaude. Desvio para a pintura. Tese de Doutorado. São Paulo: USP/ECA, 1998. https://archive.org/stream/thories189019100deniuoft\#page/n9/mode/2up

KLEE, Paul. Diários. São Paulo: Martins Fontes, 1990.

KOFFKA, Kurt. Princípios de psicologia da Gestalt. São Paulo: Cultrix, 1975.

NEIVA JÚNIOR, Eduardo. A imagem. São Paulo: Ática, 1986.

READ, Herbert E. As origens da forma na arte. Rio de Janeiro: Zahar, 1967.

SCHAPIRO, Meyer. Impressionismo. São Paulo: Cosac\&Naify, 2002.

WEISS, Paul. Organic forms: scientific and aesthetic aspects. In Kepes, Gyorgy. The Visual arts today. New York: Wesleyan University, 1960.

WORRINGER, Wilhelm. Abstraction and Empathy. Tradução de Michael Bullock. New York: International University Press, 1953

ZAMBONI, Silvio Perini. Fotografia e pintura: uma pesquisa em linguagem visual. In VENTURELLI, Suzete (org.). Arte e Tecnologia: intersecções entre arte e pesquisa tecno-científicas. $1^{\text {a }}$ ed. v. 1 . Brasília: UnB/Pós-Graduação de Arte DI/ldA, 2007. 